\title{
The Relationship between Sociodemographic Characteristics and Perception of Family Functionality in 12-15-Year-Old Students
}

\author{
12-15 Yaşlarındaki Çocukların Sosyodemografik Özellikleri ve Aile \\ İşlevselliği Algısı Arasındaki İlişki
}

Ferdağ YILDIRIM ${ }^{l}$, Zeynep TEMEL MERT ${ }^{l}$

\begin{abstract}
Aim: The aim of this study is to determine the relationship between family functionality perceptions of $12-15$-year-old middle school students and sociodemographic variables. Methods: This descriptive study was conducted with 859 children between the ages of 12-15 in three primary schools. Data were collected using a survey form containing 14 questions about the students' sociodemographic characteristics and the Family Assessment Scale (FAS) consisting of 60 items were used. Results: It was found that the highest average score of the students was in the 'roles' sub-dimension (28.81 \pm 2.71$)$ and the lowest average score was in the 'problem-solving' sub-dimension (11.33 \pm 3.63$)$ of the FAS, with the age of the students and the FAS sub-dimension. It was determined that the difference between all dimensions, gender, and "behavior control" was significant $(\mathrm{p}<0.05)$. The difference between maternal education level and all of the FAD sub-dimensions $(\mathrm{p}<0.05)$, and father education level and all sub-dimensions except problem-solving (Communication, Roles, Emotional Responsiveness, Showing Due Care, Behavior Control, General Functions) were significant ( $\mathrm{p}<0.05)$. 0.05), among all sub-dimension items (PÇ, İLT, R, DTV, GIG, GI) except for 'behavior control' and family income level $(\mathrm{p}<0.05)$, children whose mothers and fathers are separated were 'showing the necessary attention' and it was determined that the difference between the sub-dimension mean scores of behavioral control were significant ( $<<0.05)$. Conclusion: One of the most important results of this study is that as the education level of mothers increases, students perceive their families more functional. Likewise, as the family income level increases, students perceive their families as more functional. This study is important in terms of determining the functional and nonfunctional areas of the family.
\end{abstract}

Keywords: Family functioning, child, nursing.

\section{ÖZET}

Amaç: Bu araştırmanın amacı, 12-15 yaşları arasındaki öğrencilerin aile işlevselliği algıları ve sosyodemografik değişkenlerle ilişkinin belirlenmesidir. Gereç ve Yöntem: Tanımlayıcı tipteki bu araştırma üç ilköğretim okulunda 12-15 yaş aralığında olan 859 çocuk ile gerçekleştirilmiştir. Veri toplama aracı olarak, öğrenciler ve ailelerinin sosyodemografik özelliklerini içeren 14 soruluk anket formu ve 60 maddeden oluşan Aile Değerlendirme Ölçeği (ADÖ) kullanılmıştır.

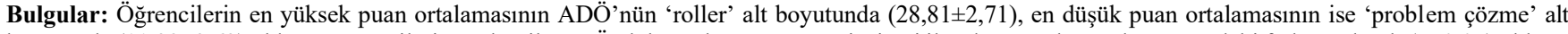
boyutunda $(11,33 \pm 3,63)$ olduğu, öğrencilerin yaşları ile ADÖ alt boyutlarının tümü, cinsiyeti ile "davranış kontrolü" arasındaki farkın anlamlı ( $<<0.05)$ olduğu belirlenmiştir. Anne eğitim durumu ile ADÖ alt boyutlarının tümü $(\mathrm{p}<0.05)$, baba eğitim düzeyi ile de problem çözme dışındaki alt boyutların tümü (İletişim, Roller, Duygusal Tepki Verebilme, Gereken İlgiyi Gösterme, Davranış Kontrolü, Genel İşlevler) arasındaki farkın anlamlı (p<0.05) olduğu, 'davranış kontrolü' dışındaki tüm alt boyut maddeleri ile (PÇ, ILLT, R, DTV, GİG, GI) aile gelir düzeyi arasında ( $\mathrm{p}<0.05)$, annesi ve babası ayrı yaşayan çocukların 'gereken ilgiyi gösterme' ve 'davranış kontrolü’ alt boyut puan ortalamaları arasındaki farkın anlamlı $(p<0.05)$ olduğu belirlenmiştir. Sonuç: Bu çalışmanın en önemli sonuçlarından biri anne eğitim düzeyi arttıkça, öğrencilerin ailelerini daha işlevsel algıladıklarıdır. Aynı şekilde aile gelir düzeyi arttıkça da öğrenciler ailelerini daha işlevsel algılamaktadırlar. Bu çalışma ailenin işlevsel olduğu ve olmadığı alanların belirlenmesi açısından önem taşımaktadır.

Anahtar Kelimeler: Aile işlevselliği, çocuk, hemşirelik.

Received / Geliş tarihi: 06.11.2020, Accepted / Kabul tarihi: 01.08.2021

${ }^{1}$ University of Cumhuriyet, Faculty of Health Sciences, Department of Nursing, Sivas/ Turkey

*Address for Correspondence / Yazışma Adresi: Zeynep Temel-Mert, University of Cumhuriyet, Faculty of Health Sciences, Department of Nursing, Sivas/ Turkey, 58140 Sivas/Turkey, E-mail: z.temell@gmail.com

Yıldırım F, Temel Mert Z. The Relationship between Sociodemographic Characteristics and Perception of Family Functionality in 12-15-Year-Old Students. TJFMPC, 2021;15(4): 676-684.

DOI: $10.21763 /$ tjfmpc.822299 


\section{INTRODUCTION}

The family is the most basic social unit upon which society is built, therefore healthy families are considered one of the important precursors for a society's general health. There is a direct relationship between healthy childhood and adolescence conditions, healthy life experiences and healthy family system. ${ }^{1,2}$ The family, which is a part of our culture and hand down all its values from generation to generation by being influenced through every situation of the society, is an important social institution for healthy child development. ${ }^{3}$ Like many social institutions, the family has not lost its place, importance and value in any society, despite the important changes it has undergone throughout human history and the differences in its functions, and has continued to be a basic functional element and core of the society. ${ }^{4,5}$ As it affects the development and functions of children through its roles, communication patterns and emotional environment ${ }^{6}$, the family can be defined as a system formed in order for children to complete their development as "a good person" and to meet their needs. ${ }^{7}$

As in all times, even today, a wellfunctioning family in which members are psychologically healthy, establish satisfying communication, have little conflict with each other and adapt easily to developmental changes can be defined as a healthy/functional family. ${ }^{8}$ Families that fulfill their functions at the expected level are considered functional, whereas those that do not function properly due to impaired intra-familial interaction are defined as dysfunctional families. ${ }^{9,10}$ Ryan et al. (2005) argue that family functionality is one of the indicators of the quality of life of a family and can be measured by its effectiveness in meeting the needs of its members. ${ }^{11}$

According to the McMaster Model of Family Functioning, one of the common family approaches, the family is the most important system of all systems in which an individual is located. The McMaster Model of Family Functioning classifies family functionality as healthy or unhealthy. It does not evaluate family functionality as a whole, but by whether the different dimensions of the model are functional or not. Accordingly, this model basically evaluates the family under six dimensions, including problem-solving, communication, roles, affective responsiveness, affective involvement, and behavior control. $^{12}$

Problem-Solving (PS) refers to the problems that threaten family integrity and its ability to cope with stressful situations. In functional families, communication (COM) should be open, bidirectional, and positively focused, allowing family members to reveal their thoughts and feelings. Individuals continue communication by sharing feedback about their life experiences. Communication between family members is based on tolerance and sincerity. Roles (R) are related to a family's skills of creating and maintaining behavioral models about how it handles and fulfills different family duties. In a healthy functioning family, members undertake roles and responsibilities, depending on family development dynamics. ${ }^{13}$ In families where roles are not shared properly, family members receive poor instrumental and emotional support, whereby the family's basic needs are not met. ${ }^{11}$ Affective Responsiveness (AR) refers to whether family members can express their feelings clearly and show the most appropriate response to stimuli. In this dimension, comforting feelings such as love, affection, happiness, and fun are considered healthy emotions, while negative feelings such as unhappiness, anger, disappointment and depression represent immediate emotions. Uncontrolled emotional reactions especially affect children and young people negatively. Affective Involvement (AI) evaluates the interest, care and love that family members show to each other, and their involvement in each other's activities. ${ }^{14}$ Behavioral Control (BC) dimension determines the level of family members to set standards and rules for each other's behaviors or to discipline their behaviors. ${ }^{15,16,17}$

Functional families have good social relations and are approved in society. They have not only organized and flexible lifestyles, but also routines. The family has a permanent residence, whereby residential changes are made on a planned basis. Functional families support children in the growth and development process. ${ }^{18}$ Children need help to be guided for their behaviors, gain values, and learn about their social responsibilities, and the family provides this help to them. ${ }^{18}$ This is valid for children of all ages including adolescence. The family makes several contributions to children by raising their awareness of being an individual and a member in the family and society, preparing them for being accepted as a social person in the society, creating a role model for them to adopt social and cultural values, solving the problems they have while adopting/adapting to the society, and helping them adopt accepted behaviors in the society. ${ }^{19}$ Fulfillment of these functions properly, that is, keeping a healthy structure by the family is associated with some variables, including family togetherness, place of residence, parental education level, and family income. Whether the family is functional or not functional depends on its basic socioeconomic characteristics and social facilities. ${ }^{20}$ The family, whose necessary functions have been studied in detail in recent years, is still the most important element of social structure. Since the 
family is the most basic social structure and healthy families are considered one of the important precursors for a society's general health, nursing studies on this issue have also increased considerably. Nurses deal with the health problems of individuals with their physical, mental, social, and cultural dimensions. It develops an individualcentered approach towards the individual, family, and society. Taking protective and strengthening nursing research on the family will support the increase of family functionality. The main purpose of this study is to show how some basic sociodemographic characteristics of parents such as cohabitation, education level and income status affect family functionality. In this regard, this study aimed to examine whether a group of students aged 12-15 years perceive their families as functional.

\section{METHODS}

This descriptive research was conducted in the spring semester of 2018-2019 academic year, in April and May, during a 9-week period in which students from Turkey-Sivas Cumhuriyet University Faculty of Health Sciences Nursing Department of Child Health and Diseases Nursing were practicing, with 859 students aged 12-15 in three secondary schools. It was conducted to evaluate perceived family functionality. Due to the differences that the students can show depending on the economic and cultural structure of their families, a certain number of schools in the regions with the same economic and cultural structure were chosen as the application area. In addition, children with special needs and chronic diseases in their families are excluded.

\section{Sample of Study}

The population was composed of all students in the 5 th, 6th, 7th, and 8th grades in three schools. No sampling method was used in order to reach the entire population, and accordingly, the sample consisted of 859 students who were at the school at the time of the study and agreed to participate in the study.

\section{Data Collection}

For conducting the study, the institutional permission was obtained from both Sivas Provincial Directorate of National Education and school administrators. Before collecting the data, the school management, school counselors, classroom/branch teachers, and students were informed about the study, and then students who agreed to participate in the study were determined. On the day of the study, data collection tools were distributed and collected under the supervision of school counselors and nursing third-grade students. Each student took approximately 20 minutes to fill out the forms.

\section{Data Collection Tools}

Data were collected using a personal information form and a 60-item "Family Evaluation Scale" developed by Wesley and Epstein (1983) and adapted into Turkish by Bulut (1990) in order to determine how students perceive their families' functionality ${ }^{21}$

Personal Information Form: The form was prepared by the researcher in line with the literature and consists of a total of 14 questions about socio-demographic characteristics of children (age, gender, grade) and parents (education level, occupation, employment status, monthly family income).

Family Assessment Scale (FAS): The scale was obtained by clinical applications of the McMaster Model of Family Functioning on families. Its validity and reliability study for Turkish language was performed by Bulut (1990). ${ }^{21}$ This is a fourpoint Likert-type self-assessment scale with response options including "totally agree", "strongly agree", "slightly agree" and "totally disagree". The scale evaluates family functionality in general terms (GF; 12 items; Cronbach $\alpha=0.091$ ) and under six dimensions including problem-solving (PS; 6 items; Cronbach $\alpha=0.87$ ), communication (COM; 9 items; Cronbach $\alpha=0.89$ ), roles (R; 11 items, Cronbach $\alpha$ $=0.73$ ), affective responsiveness (AR; 6 items; Cronbach $\alpha=0.70$ ), affective involvement (AI; 7 items; Cronbach $\alpha=0.79$ ) and behavior control (BC; 9 items; Cronbach $\alpha=0.86$ ). A score of 2.0 or above from any scale dimension indicates unhealthiness, that is, unhealthy family function (Onan et al.). The FAS can be applied individually to all family members over the age of 12 .

\section{Ethical Considerations}

Before starting the study, the ethical approval was obtained from the Sivas Cumhuriyet University Non-Invasive Clinical Research Ethics Committee (decision no. 2018/05-20), and an institutional permission from the management of schools where the study was conducted. After receiving a written consent from students who participated in the study, data were collected using face-to-face interview technique. They were explained that the data would only be used for the research purpose, whereby confidentiality would be strictly ensured.

\section{Data Evaluation}

Data were evaluated using SPSS 20 (Statistical English Packet for Social Science) program. If the students' FAS subscale mean scores were equal to or less than 2, they were considered to have healthy family functions, whereas if their mean scores were 
greater than 2, then they were considered to have unhealthy family functions. ANOVA, which is the parametric equivalent of student's t-test, and Mann Whitney $U$ test, which is the non-parametric equivalent of student's t-test, were used to check the significance of the difference between independent variables with two subgroups whose effects on a dependent variable were investigated. A p-value less than 0.05 was considered statistically significant.
The general purpose of this study is to reveal the relationship between sociodemographic variables and family functions. The data obtained from the children within the scope of the study was evaluated in two ways. Table 1 presents the characteristics of both students (age, gender) and their parents (education level, family income, and status of cohabitation), and Tables 2 and 3 show the results of statistical analyzes performed to determine whether these variables affect family functions.

\section{RESULTS}

Table 1: Distribution of Students and Their Families by Personal Characteristics $(\mathrm{n}=829)$

\begin{tabular}{|c|c|c|}
\hline & Number & $\%$ \\
\hline \multicolumn{3}{|l|}{ Age of Children } \\
\hline 12 age & 387 & 46,7 \\
\hline 13 age & 236 & 28,5 \\
\hline $14-15$ age & 206 & 24,8 \\
\hline \multicolumn{3}{|l|}{ Gender of Children } \\
\hline Famele & 467 & 56,3 \\
\hline Male & 362 & 43,7 \\
\hline \multicolumn{3}{|c|}{ Family Coexistence Status } \\
\hline Lives with parents & 761 & 91,8 \\
\hline Parents are separate & 68 & 8,2 \\
\hline \multicolumn{3}{|c|}{ Mother Education Status } \\
\hline Illiterate & 20 & 2,4 \\
\hline Literate & 28 & 3,4 \\
\hline Primer Education & 237 & 28,6 \\
\hline Seconder Education & 236 & 28,5 \\
\hline High school & 209 & 25,2 \\
\hline University & 84 & 10,1 \\
\hline \multicolumn{3}{|c|}{ Fother Education Status } \\
\hline Illiterate & 7 & 0,8 \\
\hline Literate & 24 & 2,9 \\
\hline Primer Education & 108 & 13,0 \\
\hline Seconder Education & 162 & 19,5 \\
\hline High school & 313 & 37,8 \\
\hline University & 192 & 23,2 \\
\hline \multicolumn{3}{|l|}{ Family Income Level } \\
\hline Low & 46 & 5,5 \\
\hline Middle & 642 & 77,4 \\
\hline High & 141 & 17,0 \\
\hline \multicolumn{3}{|l|}{ Mother's Job } \\
\hline Yes & 156 & 18,8 \\
\hline No & 658 & 79,4 \\
\hline \multicolumn{3}{|l|}{ Mother's Job } \\
\hline Yes & 750 & 90,5 \\
\hline No & 57 & 6,9 \\
\hline
\end{tabular}

According to Table $1,46.7 \%$ of the students were 12 years old, $56.3 \%$ were female, and $91.8 \%$ lived with their families. In addition, $57.1 \%$ of the mothers were primary and secondary school graduates, $35.3 \%$ were high school and university graduates, and $37.8 \%$ of the fathers were high school graduates. Moreover, $79.4 \%$ of the mothers were unemployed, $90.5 \%$ of the fathers were employed, and $77.4 \%$ of the families had moderate-income level.

Table 2 shows the students' mean scores on FAS total scale and subscales. The students obtained the highest mean scores on the "roles" subscale, followed by "general functions", "behavior control", "communication", "affective responsiveness" and "problem-solving".

\begin{tabular}{|l|c|c|}
\hline Table 2: Family Functioning Mean Scores & Average Scores of the Scale \\
\hline Scale Sub-Dimensions & $\begin{array}{l}\text { Lower and Upper Values Taken from the } \\
\text { Scale in This Study }\end{array}$ & $147,14 \pm 10,73$ \\
\hline FAD Total & $125.00-198.00$ & $11,33 \pm 3,63$ \\
\hline Problem-solving & $6.00-24.00$ & $22,19 \pm 3,39$ \\
\hline Comunication & $15.00-34.00$ & $28,81 \pm 2,71$ \\
\hline Roles & $21.00-40.00$ & $15,74 \pm 1,99$ \\
\hline Showing Attention & $14.00-28.00$ & $21,08 \pm 1,95$ \\
\hline Emotional Response & $11.00-23.00$ & $23,81 \pm 2,18$ \\
\hline Behavior Control & $15.00-32.00$ & $24,22 \pm 2,48$ \\
\hline General Functions & $18.00-38.00$ & \\
\hline
\end{tabular}


According to Table 3, the difference between the students' age and all FAS subscales was significant $(p<0.05)$.

In addition, the difference between the students' gender and behavioral control subscale was significant $(p<0.05)$, whereas the difference between the groups in terms of other subscales and total scale mean scores was insignificant ( $p>0.05$ ). As the age of students increased, their FAS total and subscales mean scores increased, where the students had the highest mean score on the subscale of "roles", followed by "communication", "general functions", and "affective responsiveness". When the mean scores of the students were examined by gender, the female students were found to have higher mean scores on all subscales except for problem-solving (female $=11.40 \pm 3.64$, male $=$ $11.24 \pm 3.62)$ than the male students.

\begin{tabular}{|c|c|c|c|c|c|c|c|}
\hline Sociodemographic Features & PS & $\mathbf{C}$ & $\mathbf{R}$ & ER & $\mathbf{S A}$ & BC & GF \\
\hline \multicolumn{8}{|l|}{ Students' Age } \\
\hline 12 age $(n=388)$ & $11,09 \pm 3,53$ & $17,30 \pm 4,55$ & $18,61 \pm 5,02$ & $10,66 \pm 3,43$ & $13,58 \pm 3,68$ & $15,79 \pm 3,42$ & $17,00 \pm 3,95$ \\
\hline 13 age $(n=235)$ & $11,25 \pm 3,58$ & $17,70 \pm 4,34$ & $19,45 \pm 4,99$ & $10,86 \pm 3,47$ & $13,71 \pm 3,57$ & $16,48 \pm 3,56$ & $17,41 \pm 4,22$ \\
\hline $14-15$ age $(n=204)$ & $11,89 \pm 3,82$ & $18,41 \pm 4,51$ & $21,46 \pm 5,37$ & $11,75 \pm 3,32$ & $14,61 \pm 4,01$ & $16,66 \pm 4,15$ & $18,01 \pm 4,55$ \\
\hline $\mathrm{F}$ & 3,37 & 4,09 & 20,86 & 6,96 & 5,39 & 4,75 & 3,92 \\
\hline $\mathrm{p}$ & $\mathbf{0 , 0 3 5}$ & 0,017 & 0,000 & 0,001 & 0,005 & 0,009 & $\mathbf{0 , 0 2 0}$ \\
\hline \multicolumn{8}{|l|}{ Gender of Students } \\
\hline Famele & $11,40 \pm 3,64$ & $17,57 \pm 4,52$ & $19,04 \pm 5,23$ & $10,87 \pm 3,45$ & $13,61 \pm 3,70$ & $15,98 \pm 3,44$ & $17,16 \pm 4,07$ \\
\hline Male & $11,24 \pm 3,62$ & $17,84 \pm 4,47$ & $20,21 \pm 5,14$ & $11,13 \pm 3,43$ & $14,21 \pm 3,81$ & $16,48 \pm 3,92$ & $17,62 \pm 4,34$ \\
\hline $\mathrm{F}$ & 0,255 & 0,381 & 0,000 & 0,107 & 0,661 & 6,361 & 1,994 \\
\hline $\mathrm{p}$ & 0,614 & 0,537 & 0,996 & 0,743 & 0,416 & 0,012 & 0,158 \\
\hline
\end{tabular}

Test=Mann Whitney U, PS=Problem-Solvıng , C=Comunication, R=Rolls, ER=Emotıonal Response, SA=Showıng Attention, $\mathrm{BC}=\mathrm{Behavior}$ Control, GF= General Functions

\begin{tabular}{|c|c|c|c|c|c|c|c|}
\hline Sociodemographic Features & PS & $\mathbf{C}$ & $\mathbf{R}$ & ER & $\mathbf{S A}$ & BC & GF \\
\hline \multicolumn{8}{|l|}{ Family Unity } \\
\hline Parents together & $11,31 \pm 3,66$ & $17,66 \pm 4,51$ & $19,48 \pm 5,23$ & $10,88 \pm 3,38$ & $13,79 \pm 3,67$ & $16,14 \pm 3,58$ & $17,30 \pm 4,23$ \\
\hline Separate parents & $11,54 \pm 3,23$ & $17,98 \pm 4,38$ & $20,32 \pm 5,12$ & $12,11 \pm 3,89$ & $14,79 \pm 4,58$ & $16,91 \pm 4,44$ & $18,05 \pm 3,74$ \\
\hline $\mathrm{F}$ & 1,146 & 0,142 & 0,146 & 2,890 & 0,775 & 7,621 & 1,071 \\
\hline $\mathrm{P}$ & 0,285 & 0,707 & 0,703 & 0,089 & $\mathbf{0 , 0 1 0}$ & 0,006 & 0,301 \\
\hline \multicolumn{8}{|l|}{ Mother Education Status } \\
\hline Illiterate & $12,85 \pm 4,29$ & $19,90 \pm 4,57$ & $23,30 \pm 6,81$ & $13,85 \pm 3,85$ & $16,15 \pm 3,83$ & $17,60 \pm 4,08$ & $21,10 \pm 5,71$ \\
\hline Literate & $11,32 \pm 3,41$ & $18,46 \pm 4,13$ & $20,07 \pm 5,11$ & $12,25 \pm 3,92$ & $15,17 \pm 382$ & $16,92 \pm 3,66$ & $17,89 \pm 4,24$ \\
\hline Primary education & $11,29 \pm 3,84$ & $18,34 \pm 4,77$ & $19,96 \pm 5,06$ & $11,27 \pm 3,24$ & $13,89 \pm 3,72$ & $16,49 \pm 3,74$ & $17,47 \pm 4,16$ \\
\hline Secondary education & $11,34 \pm 3,60$ & $17,38 \pm 4,22$ & $19,48 \pm 5,21$ & $10,91 \pm 3,29$ & $14,13 \pm 3,95$ & $16,20 \pm 3,63$ & $17,12 \pm 3,86$ \\
\hline High school & $11,57 \pm 3,48$ & $17,71 \pm 4,55$ & $19,18 \pm 5,10$ & $10,63 \pm 3,56$ & $13,42 \pm 3,67$ & $16,03 \pm 3,54$ & $16,21 \pm 3,64$ \\
\hline University & $10,24 \pm 3,20$ & $15,87 \pm 3,90$ & $18,08 \pm 4,85$ & $9,80 \pm 3,08$ & $13,15 \pm 3,04$ & $15,13 \pm 3,31$ & $17,33 \pm 4,18$ \\
\hline $\mathrm{F}$ & 2,402 & 5,197 & 4,040 & 6,513 & 3,630 & 2,653 & 4,807 \\
\hline $\mathrm{P}$ & 0,036 & $\mathbf{0 , 0 0 0}$ & 0,001 & 0,000 & $\mathbf{0 , 0 0 0}$ & 0,022 & 0,000 \\
\hline \multicolumn{8}{|l|}{ Mother Education Status } \\
\hline Illiterate & $12,57 \pm 5,19$ & $20,28 \pm 4,68$ & $24,00 \pm 6,60$ & $14,71 \pm 5,34$ & $17,14 \pm 4,14$ & $19,57 \pm 3,40$ & $22,00 \pm 6,78$ \\
\hline Literate & $11,54 \pm 3,25$ & $18,54 \pm 4,74$ & $21,95 \pm 5,52$ & $12,33 \pm 4,34$ & $15,08 \pm 5,67$ & $17,95 \pm 3,78$ & $17,75 \pm 4,39$ \\
\hline Primary education & $11,83 \pm 3,87$ & $18,93 \pm 4,49$ & $20,57 \pm 5,35$ & $11,74 \pm 3,48$ & $14,53 \pm 4,14$ & $16,83 \pm 3,95$ & $18,18 \pm 4,92$ \\
\hline Secondary education & $11,23 \pm 3,55$ & $17,95 \pm 4,29$ & $20,11 \pm 5,08$ & $11,47 \pm 3,45$ & $14,40 \pm 3,69$ & $16,12 \pm 3,69$ & $17,73 \pm 4,08$ \\
\hline High school & $11,46 \pm 3,49$ & $17,78 \pm 4,51$ & $19,28 \pm 4,78$ & $10,92 \pm 3,17$ & $13,58 \pm 3,53$ & $16,22 \pm 3,45$ & $17,15 \pm 3,78$ \\
\hline University & $10,87 \pm 3,80$ & $16,42 \pm 4,40$ & $18,55 \pm 5,66$ & $9,91 \pm 3,32$ & $13,32 \pm 3,54$ & $15,51 \pm 3,68$ & $16,65 \pm 4,14$ \\
\hline $\mathrm{F}$ & 1,277 & 5,545 & 4,881 & 8,132 & 4,093 & 4,358 & 4,171 \\
\hline $\mathrm{P}$ & 0,272 & $\mathbf{0 , 0 0 0}$ & $\mathbf{0 , 0 0 0}$ & $\mathbf{0 , 0 0 0}$ & 0,001 & 0,001 & 0,001 \\
\hline \multicolumn{8}{|l|}{ Family Income Level } \\
\hline Low & $12,97 \pm 4,08$ & $19,19 \pm 5,21$ & $23,84 \pm 6,77$ & $12,54 \pm 3,71$ & $15,65 \pm 4,16$ & $17,15 \pm 3,82$ & $19,32 \pm 4,53$ \\
\hline Middle & $11,27 \pm 3,55$ & $17,67 \pm 4,34$ & $19,39 \pm 4,93$ & $10,85 \pm 3,34$ & $13,77 \pm 3,73$ & $16,13 \pm 3,57$ & $17,21 \pm 4,11$ \\
\hline High & $11,07 \pm 3,72$ & $17,27 \pm 4,88$ & $18,87 \pm 5,34$ & $11,07 \pm 3,67$ & $13,73 \pm 3,59$ & $16,21 \pm 4,02$ & $17,41 \pm 4,35$ \\
\hline $\mathrm{F}$ & 5,207 & 3,183 & 17,710 & 5,231 & 5,496 & 1,658 & 5,477 \\
\hline $\mathrm{P}$ &, 006 &, 042 &, 000 &, 006 &, 004 &, 191 & ,004 \\
\hline
\end{tabular}

Test=Mann Whitney U, PS=Problem-Solvıng, $\mathrm{C}=$ Comunication, $\mathrm{R}=$ Rolls, ER= Emotional Response, $\mathrm{SA}=$ Showıng Attentıon, $\mathrm{BC}=\mathrm{Behavior}$ Control, GF= General Functions

According to Table 4, the difference between the "effective involvement" and "behavior control" mean scores of students with and without separated parents was significant $(\mathrm{p}<0.05)$, and the difference between the groups in terms of other subscales was insignificant $(\mathrm{p}>0.05)$.
In addition, the difference between the students' mean scores on all subscales according to the mother's education level was significant ( $p$ $<0.05$ ). The mean scores on all subscales obtained by the students whose mothers did not go to school and are still illiterate and of those whose mothers did not go to school but learned to read and write were higher than the mean scores of those whose mothers 
graduated from primary school, secondary school, high school and university.

When the education status of fathers and children's perceptions of family functionality were examined, the difference between their mean scores on all subscales except for problem-solving was significant $(\mathrm{p}<0.05)$. The students whose fathers did not attend school and who were illiterate had higher mean scores on all subscales than those whose fathers graduated from primary school, secondary school, high school and university.

As can be seen from Table 4, there was a significant difference between family income level and all FAS subscales except for behavior control ( $p$ $<0.05$ ), where the students with poor family income had higher FAS total and all subscale mean scores than those with moderate and high family income.

\section{DISCUSSION}

Family functionality includes patterns that positively affect the family's development in matters that are important for the emotional, social and cognitive development of family members, especially children. Families with high family functionality have certain boundaries and rules. Members of these families consider themselves as a valuable part of their family, use open communication patterns within the family, and can express themselves easily if needed. On the other hand, families with low family functionality do not have functional habits to solve their problems, and often there is a noticeable confusion in the family. ${ }^{22}$ Family environment affects a child's perceptions of environment, himself and family. ${ }^{23}$ Children who grow up in a family environment with dysfunctions cannot develop normally, and their parents do not aware of that their children have distinctive personalities, capacities, abilities, natural tendencies and interests, and should be promoted and guided accordingly. In such a family environment, as children cannot explore the world, develop abilities by interacting with social environment and create sense of self-confidence, their physical, mental and emotional development is prevented. Moreover, poor health in family functions is reflected not only in a person's family relations, but also in his close and distant relationships with other people, and may appear as one of the causes of psychosocial/social problems. ${ }^{24}$ From this point of view, the students' total FAS score was found to be $147.14 \pm 10.73$ without taking an average (Table 2). Bulut (1990) has reported that an average FAS score above 2.0 indicates unhealthy family functions.

According to the students, the functions that their families could not fulfill were "roles", "general functions", "behavior control", "communication", "affective responsiveness" and "problem-solving", respectively (Table 2). The main factor why the students perceived the "roles" function as the unhealthiest function of their family may be the fatherhood roles perceived by fathers in traditional family understanding only as making a living for the house, providing financial support to family members and keeping discipline in the family. ${ }^{24,25}$ In today's societies where a continuous and rapid change is experienced, differentiation in the cultural structure has changed maternal and paternal roles. Around thirty years ago, maternal and paternal roles and responsibilities were separated from each other with clear boundaries, but today this distinction is not as sharp as before. ${ }^{26}$ Especially as mothers have been involved in work life, fathers have started to take care of their children by taking more responsibility in their care and education. ${ }^{27}$ However, despite these changes, according to the results of the present study, fathers are considered to need time to adopt/adapt their new roles.

The second unhealthy family function was "general functions" with a mean score of $24.22 \pm 2.48$, followed by "behavior control". The unhealthy "behavior control" function may be attributed to the fact that the basic function of the Turkish family structure is to establish authority over its members. In addition to family relations; environmental groups, relatives and human relations in suburbs may have a negative effect on "behavior control" function.

The fourth unhealthy family function was "communication" with a mean score of $22.19 \pm 3.39$ (Table 2). Communication of both parents and other family members with the child determines his place in the family. Healthy relationships in childhood, in which the basis of children's future lives are formed, is of great importance for child development. What kind of an individual the child, who starts to perceive himself and his environment during this period, will be in the future is determined by his experiences in this period. Both the family and intra-family relationships have a significant effect on the child. ${ }^{28}$ In this study, it is seen that the first function that the family performs in a healthy way is 'problemsolving $=11.33 \pm 3.63^{\prime}$ and the second function that follows is 'showing the necessary attention $=15.74 \pm 1.99$ '. (Table 2). Studies show that children who grow up in families with poor problemsolving skills have intense verbal and aggressive behaviors, poor coping mechanisms, and risk of psychological problems such as depressive moods. Problem-solving problems in the family mostly affect children with poor coping abilities. ${ }^{29}$ From this point of view, it is a positive family function for children that families are sensitive to emphasize problem-solving and affective involvement than to perform other functions. Family members are 
expected to perceive one member's problem as a problem for the whole family, and to have necessary affective involvement for each other. Moreover, although the socioeconomic characteristics of the students' families in this study, including poor family income status, unfavorable work conditions and low educational levels, are considered to prevent their parents from performing the affective involvement function, the result suggesting that the parents had the necessary affective involvement for their children is equally important.

According to the results of the analysis performed to understand the relationship between family functionality and children's characteristics, when the family functionality was examined by age, the students aged 12-13 years had higher FAS total and subscales mean scores than those aged 14-15 years, that is, the functionality of their families decreased as their age increased (Table 3). When the family functionality was examined by gender, the male students had higher mean scores on all subscales except for problem-solving than the female students, that is, the boys had lower family functionality than the girls (Table 3 ). Contrary to these results, one study found that girls had higher mean scores on all subscales except for problemsolving than boys (girls $=11.40 \pm 3.64$, boy $=$ $11.24 \pm 3.62){ }^{2}$ Another study examined the adjustment level according to family function perceptions of adolescents, and determined that adolescents perceived their family functions as healthy except for "affective involvement". ${ }^{30}$ One another study determined that adolescents perceived their family as unhealthy in terms of family functions including "roles", "affective involvement" and "behavior control", and as healthy in terms of "problem-solving", "general functions", "communication" and "affective responsiveness". 30 These age-related results suggest that adolescents may look at their families more critically and therefore perceive their families as unhealthy. Another study found a significant difference between female and male adolescents in terms of family functions including roles $(Z=2.79 ; p=0.005)$, behavior control $(Z=2.39 ; \mathrm{p}=0.01)$ and general functions $(Z=2.42 ; p=0.01)$. That is, female adolescents perceived family functionality more negatively than male ones. ${ }^{15}$

The research has been handled in terms of parents and children living together, parents' educational status and family income level. Accordingly, the students with separated parents had higher mean scores on all FAS subscales than those with married parents where the difference between their mean scores on the subscales of "affective involvement" and "behavior control" was significant $(p<0.05)$ (Table 4). It is important for children that their parents live together. One study has shown that parents who live together can help the child learn social skills such as sharing, negotiation and reconciliation. ${ }^{31}$ Another study reported that children with extended family had higher "affective responsiveness" mean score $(2.11 \pm 0.7)$ than those with other family types, where the difference between the groups was statistically significant ( $p$ $<0.05){ }^{23}$ In her descriptive study to determine the effects of an autistic child and family characteristics on family functions, ${ }^{32}$ found that the difference between the perceived family functions total mean scores was insignificant according to family type. ${ }^{32}$ One study found that compared to those in other family types, mothers in extended families had more problems regarding family communication, distribution of family roles, inappropriate emotional reactions, affective family involvement, and performance of general family functions. ${ }^{33}$

Çakıcı (2006) revealed that mothers' age and employment status did not affect the motherchild relationship, whereas their education status affected it. As mothers' educational level increased, they had more positive relationship with their children. ${ }^{28,34}$ In our study, it was determined that the education level of the mother positively affected all functions of the family ( $p<0.05$ ), while the education level of the father positively affected the functions of 'general functions, role, emotional response, showing the necessary attention and behavior control $(\mathrm{p}<0.05) .{ }^{35}$ Dil and Bulantekin (2011) found that students whose mothers were college/university graduates had lower mean score on "affective involvement" subscale $(1.67 \pm 0.15)$ than other groups, where the difference between the groups was statistically significant. ${ }^{23}$ Kurbaş and Özkan (2013) found no statistically significant difference between the students' mean scores on FAS total scale and all subscales except for "affective responsiveness" and "behavior control" according to maternal education level. ${ }^{36}$ Türkleş et al. (2013) determined that illiterate women had more problems in their families regarding the family functions of "affective responsiveness", "affective involvement" and "communication" than those with high school degree or above. ${ }^{33}$ Gök (2013) found that higher paternal education positively affected family functionality dimensions including "affective responsiveness", "affective involvement", "behavior control" and "general functions". ${ }^{37}$ Nazlı (1997) has reported that as parental education level increases, family functions become healthier, that family functions change according to parents' occupations, and that those unemployed women (housewives) perform their family functions more unhealthy than employed ones. ${ }^{38}$ Bulut (1993) found that those with low education level perceived family functions unhealthy, whereas those with higher education level were more tolerant and perceived family functions healthy. Another study determined that the higher 
the mothers' education levels, the more positive their relationships with their children. ${ }^{28}$

The present study found a significant statistical relationship between family income level and all FAS subscales except for "behavior control" $(p<0.05)$ (Table 4). An insufficient family income may cause many problems in family life, affecting family functions negatively. ${ }^{39,28}$ Çakıcı (2006) examined the family functions of families with children (6 years old) from lower and upper socioeconomic levels, and reported the socioeconomic level as a determinant in family functions. $^{34}$ Accordingly, families from upper socioeconomic level performed more unhealthy functions in terms of communication, family roles, affective responsiveness, behavior control, and general functions, and those from lower socioeconomic level performed more unhealthy functions in terms of problem-solving and affective involvement. ${ }^{28}$ Karaca et al. (2013) found that children with sufficient family income perceived family functions of "problem-solving", "roles" and "affective involvement" as healthier than those with insufficient family income. ${ }^{15}$ Another study determined that parents' perception of financial income affected family functionality dimensions including "roles" and "general functions". 39

\section{CONCLUSION AND RECOMMENDATIONS}

This study evaluated family functionality of 859 students aged 12-15 years. As the most important result, it found a significant relationship between cohabitation of parents and children, parental education status, family income level and family functionality, where family separation, low parental education level, and poor family income made it difficult for the family to fulfill its functions.

Family studies should focus on effective problem-solving methods and individual/systemic problems of families and/or family members who cannot solve their problems effectively, and if necessary, further studies should be conducted for children, especially considering the effect of these problems on them. Nursing studies to promote parent-child relationships should emphasize the importance of family communication, the positive effect of meeting children's psychosocial needs on family members, and the effective parent-child communication and its effect on children.

\section{REFERENCES}

1. Tümer T. 9-11 yaş arası çocukların yaşam kalitesinin aile işlevselliği ve sosyo-demografik değişkenler açısından incelenmesi, T.C. Ege Üniversitesi, Yüksek Lisans Tezi,2018; 99-104.
2. Görgülü T. Mcmaster aile işlevleri modeli ve gömleği yırtı kırmızı gül öyküsü'nün Mcmaster modeli temelinde incelenmesi, Turkish Studies Language an Literature, 2019;14(1):99-114.

3. Tezel Şahin F, Cevher FN. Türk toplumunda aile-çocuk ilişkilerine genel bir bakış 2015. https://www.ayk.gov.tr/wp-content/uploads / 2015 /(Erişim tarihi:02.10.2020)

4. Ağacık N. Annenin aile işlevselliği algısına yönelik bir araştırma, Ankara Üniversitesi, Sağlık Bilimleri Enstitüsü Sosyal Psikiyatri Anabilim Dal, Yüksek Lisans Tezi,2007;44-56.

5. Kır İ. Toplumsal bir kurum olarak aile işlevleri. Elektronik Sosyal Bilimler Dergisi, 2011;10(36);381-404.

6. Çavuşoğlu FN. Evli çiftlerin kendi aile yapı ve işlevselliklerinin, aile orijinleri ile karşılaştırılması. Yayınlanmamış Yüksek Lisans Tezi, Gazi Üniversitesi, Eğitim Bilimleri Enstitüsü, Ankara.2007;52-68.

7. Sabatalli R, Bartle,S. Survey appoaches to the assessment of family functioning:conceptual, operational and analytical 1ssues, Journal of Marriage and Family. 1995:157.

8. Frude N. Understanding Family Problems. Chishester: John Wiley and Sons. 1991;200-228.

9. Alacahan O. Aile birliğini oluşturan faktörler ve işlevleri. C.Ü. İktisadi Ve İdari Bilimler Dergisi. 2010;11(1)289 -298.

10. Beavers R, Hampson R. The systems model of family functioning, Journal of Family Therapy. 2002;22(2):128.

11. Modanloo $\mathrm{S}$ et al. General family functioning as a predictor of quality of life in parents of children with cancer. Journal of Pediatric Nursing. 2019;44.2-8.

12. Epstein N, B Baldwin, LM, Bishop, DS. The McMaster family assessment device. Journal of marital and family therapy. 1983;9(2)171-180.

13. Emran Özbulak B, Bulut Serin N, Karaca R. Ergenlerdeki cinsiyet ve aile yapısının boyun eğici davranışları yordama gücünün araştırılması, International Conference on New Horizons in Education Proceeding Book. 2010;332-338.

14. Nazlı S. Aile Danışması. Nobel Yayın Dağıtım. Ankara.2000;4-370.

15. Karaca Gül S, ve ark. 16-20 yaş grubu ergenlerde aile işlevleri ve kişilerarası ilişki tarzının incelenmesi: bir üniversite örneklemi. Balıkesir Sağlık Bil. Dergisi.2013;2(3)139-146.

16. Modanloo $\mathrm{S}$, et al. General family functioning as a predictor of quality of life in parents of children with cancer, publication. Evaluating and Treating Families The McMaster Approach. Journal of Pediatric Nursing. 2018;44(1).

17. Dil S, Bulantekin Ö. Hemşirelik çocuklarında akademik başarı düzeyi ile aile işlevselliği ve 
kontrol odağı arasındaki ilişkinin belirlenmesi, Psikiyatri Hemşireliği Dergisi.2011;2(1):17-24.

18. Terri K, Carman S. Essentials of Pediatric Nursing. 2. edition, Newyork, Wolters Kluwer Health Lippincott Williams \& Wilkins,2013;2430.

19. Yavuzer H. Çocuk Psikolojisi, İstanbul, Remzi Kitabevi,1993;25-88.

20. Tufan B. Aile içi ilişkilerin ruh sağlığına etkisi üzerine bir inceleme. H.Ü. Sosyal Hizmetler Yüksekokul Dergisi, 1982:1(1):1.

21. Bulut I. Aile Değerlendirme Ölçeği El Kitabı. Ankara, Öz Güzeliş Matbaası, 1990;1-22.

22. Deniz İ, Göller L. Engelli çocuğa sahip ebeveynlerin aile işlevselliği ve evlilik doyumları arasındaki ilişkinin incelenmesi, Eğitim Kuram ve Uygulama Araştırmaları Dergisi, 2017;03(01)53-69.

23. Dil S, Bulantekin Ö. Hemşirelik öğrencilerinde akademik başarı düzeyi ile aile işlevselliği ve kontrol odağ 1 arasındaki ilişkinin belirlenmesi, Journal of Psychiatric Nursing. 2011;2-1:17-24.

24. Demircioğlu H, Tezel FŞ, Günindi Y. Anne babaların görüşlerine göre aile işlevleri. An International Journal of Educational Research. 2011;13-1.

25. Öztürk ED. Baba ve bebek etkileşim düzeyleri, Uluslararası Sosyal Araştırmalar Dergisi, 2018;11(60).

26. Akar T, Aksoy AB. Çocukların anne babalarına yönelik algılarının toplumsal cinsiyet bağlamında incelenmesi, Journal of Educational Sciences 2018;9(1):31-46.

27. Güngörmüş O. Baba-çocuk ilişkisi, Ana-Baba Okulu. İstanbul, Remzi Kitabevi.2003;200-235.

28. Bartan M, Tezel Şahin F. Ebeveyn-Çocuk İlişkisi Envanterinin 60-72 Aylik Çocuklarin Anne Ve Babalarina Uyarlanmasi, Dumlupınar Üniversitesi Sosyal Bilimler Dergisi, 2012; Say1 34: $185-200$

29. Kalyencioğlu D, Kutlu Y. Ergenlerin aile işlevi algılarına göre uyum düzeyleri. Florence Nightingale Journal of Nursing, 2010;18:56-62

30. Karahisar S. Ortaokul 3. ve 4. Sinifa devam eden çocukların ve annelerinin algıladıkları aile işlevlerinin karşılaştırılması ve çocukların yaşam doyumlarına etkisinin incelenmesi, Institute of Health Sciences, Child
Development and Education Program, Master Thesis, Hacettepe University. 2015;70-88.

31. Amato PR, Keith B. Parental divorce and the well-being of children: a meta-analysis. Psychol Bull 1991;110:26-46.

32. Tokuç FÖ. Otistik çocuk ve aile özelliklerinin aile işlevlerine etkisi. Institute of Health Sciences, Department of Public Health Nursing, Master's Thesis. Marmara University, 2009;6399.

33. Türkleş $S$ ve ark. Kadınlarda ruh sağlığını ve aile işlevlerini etkileyen etmenler. Journal of Anatolia Nursing and Health Sciences. 2013;16:(3) 154-162

34. Çakıcı S. Alt ve üst sosyoekonomik düzeydeki ailelerin aile işlevlerinin, anne-çocuk ilişkilerinin ve aile işlevlerinin anne-çocuk ilişkilerine etkisinin incelenmesi. Institute of Education Sciences, Unpublished Master's Thesis, Gazi University. 2006;83-98.

35. Erdoğdu MY. Suça yönlendirilen ve yönlendirilmeyen çocukların aile İlişkileri ile saldırganlık davranışlarının karşılaştırılması. Turkısh Journal of Child and Adolescent Mental Health. 2000;12-3:106-114.

36. Kırbaş ZÖ, Özkan H. Down sendromlu çocukların annelerinin aile işlevlerini algılama ve sosyal destek düzeylerinin değerlendirilmesi. Journal of Dr. Behcet Uz Pediatric Hospital, 2013;3(3):171-180.

37. Gök Akgül F. Evli kadin ve erkeklerin toplumsal cinsiyet rolleriyle ilgili algilarının aile işlevlerine yansıması. Instıtute of Socıal Sciences, Department of Social Work, Unpublished Master Thesis, Hacettepe University. 2013;65-130.

38. Nazlı, S. Aile Fonksiyonlarının Bazı Değişkenlere Göre İncelenmesi. Yayınlanmamış Doktora Tezi, Ankara, Gazi Üniversitesi, Sosyal Bilimler Enstitüsü. 1997; 150-185.

39. Coşkun D. Fiziksel engelli çocuğu olan ebeveynlerde bakım yükünün ve aile işlevlerinin değerlendirilmesi, Instıtute of Health Sciences, Child Health and Disease Nursing.Master Thesis. Ataturk University. 2013;23-37. 